\title{
The natural areas of Rome Province detected by airborne remotely sensed data
}

\author{
Rosa Maria Cavalli $\left({ }^{1}\right)$, Lorenzo Fusilli $\left({ }^{1}\right)$, Anna Guidi $\left({ }^{2}\right)$, Simone Pascucci $\left({ }^{1}\right)$, Stefano Pignatti $\left({ }^{1}\right)\left({ }^{3}\right)$, \\ Ludovico Vannicelli Casoni $\left({ }^{4}\right)$ and Maria Vinci $\left({ }^{2}\right)$ \\ $\left(^{1}\right)$ Laboratorio Aereo Ricerche Ambientali (LARA), IIA-CNR, Tor Vergata (RM), Italy \\ (2) Provincia di Roma - Dipartimento II, Roma, Italy \\ $\left(^{3}\right)$ Istituto Metodologie Analisi Ambientale (IMAA), CNR, Tito Scalo (PZ), Italy \\ $\left({ }^{4}\right)$ Provincia di Roma - Dipartimento I, Roma, Italy
}

\begin{abstract}
Rome Province with its 4 million inhabitants is one of the Italians areas with the largest urban expansion, mainly concentrated around the capital city. The uncontrolled urbanization of the past has heavily marked the landscape, especially Rome countryside and coastline. However many zones have exceeded the anthropic pressurewithout serious consequence since the sensitivity towards environmental protection has grown in recent years. Rome Province Administration has devoted special attention to the improvement and protection of its naturalistic heritage by means of a series of administrative actions, cultural initiatives and projects for environmental education. In this perspective a three-year agreement was concluded with CNR LARA focused on the study of natural vegetation by means of MIVIS (Multispectral Infrared Visible Imaging Spectrometer) remotely sensed data. This study distinguished and mapped the most important natural forests, shrub and herbaceous formations, assessed the health conditions of the arboreal vegetation, identified the areas with little water supply, and measured some environmental parameters, like temperature and surface humidity. The results achieved highlight the large botanical and naturalistic assortment and the complexity of the study-area.
\end{abstract}

Key words airborne hyperspectral remote sensing - environmental monitoring - maximum likelihood vegetation mapping

\section{Introduction}

The importance of mapping, quantifying and monitoring changes in the physical characteristics of forest cover has been widely recognized as a key element in the study of global change (Nemani and Running, 1996). Land cover, i.e. the composition and the characteristics of land

Mailing address: Dr. Lorenzo Fusilli, Laboratorio Aereo Ricerche Ambientali (LARA), IIA-CNR, Via del Fosso del Cavaliere 100, 00133 Tor Vergata (RM), Italy; e-mail: lorenzo.fusilli@lara.rm.cnr.it surface elements, is a piece of environmental information and represents an effective resource for management and policy purposes for a wide range of human activities. The location and rates of forest structural change and the degree to which landscapes respond to human disturbances require extensive investigations (Lambin, 1998; Borak et al., 2000). Among the large variety of forested ecosystems the Mediterranean comprises a vegetation form and distribution with worldwide importance being of special interest to global change research in terms of biodiversity, desertification, water resources and urbanization (Hill et al., 1995; Moreno and Oechel, 1995).

The new generation high resolution optical sensors allow new applications in Earth observation for land cover mapping by delivering new methodologies for generating land cover 
information products with high accuracy. For the remote sensing community vegetation mapping is a considerable objective for the study and monitoring of ecosystems. The rapid and cost-effective application of remote sensing to map vegetation is one of the important motivations for its utilization in land use planning to replace more time consuming and expensive field surveys. In this context, an increasing number of agencies as well as private companies with large land holdings currently use vegetation maps derived from satellite and airborne data (Congalton et al., 1993).

Rome Province Administration has long devoted its efforts to enhancing the value and protecting its historical naturalistic heritage and hence it has implemented some specific Land Management Plans for its Natural Reserves (Nature 2000 Project of the European Community). The purpose of these Management Plans is to represent a reference framework from which to undertake land management policy actions and stimulate bio-compatible activities in the respect and the safeguard of the environment. They also aim to organize all geographic, urban and environmental data in a homogeneous context, to carry out a careful analysis and intervention planning. The necessity has thus arisen to make a detailed «Map of the Main Vegetation Classes» (scale 1:10000) of the Natural Reserves recently established, and of the north-eastern area of Rome Province territory (scale 1:25000) where a detailed homogeneous cartography of vegetation has never been compiled.

The considerable extension of the area to investigate, the difficulty in approaching inaccessible places, together with the biodiversity of vegetation, led to the use of airborne remote sensing as a means of investigation. The cartography deriving from the Corine Land Cover at 1:100000 scale (1994) obtained from Landsat satellite images (ground pixel resolution of 30 $\mathrm{m})$ was not able to meet the required cartographic and thematic details. Rome Province Administration therefore started a triennial agreement with CNR-IIA/LARA to study the main vegetation covers by means of MIVIS (Multispectral Infrared Visible Imaging Spectrometer) airborne sensor.

\section{Study area}

The area investigated is of particular interest for both its botanic-naturalistic variety still intact and its historical-archaeological heritage. Local authorities, in particular Rome Province Administration, are properly improving and safeguarding this area by means of administrative provisions, cultural initiatives and projects for environmental education.

The area (fig. 1), located in the E-NE portion of Rome Province (Latium), extends from the Tiber Valley and the lightly rolling undulations of the Roman countryside, towards the sharp carbonate massif near Tivoli, and east to the mountainous ridge of the Latium Apennines. This territory has already been safeguarded to a great extent by establishing several protected areas, some important like the Natural Reserves of Nomentum, Macchia di Gattaceca, Mt. Catillo, Mt. Soratte, and the Regional Parks of Mts. Lucretili and Mts. Simbruini. The high environmental value of this area is also proved by the presence of numerous Sites of European Community Interest (SIC) and Special Protected Areas (ZPS) instituted according to the 92/43/CEE «Habitat» and 79/409/CEE «Birds» provisions.

From the point of view of flora, the area comprises several wood formations which are one of the prevailing land covers. Besides the arboreal component, the herbaceous and shrubby formations, presenting a wide ecological and floristic differentiation, are also well represented. According to the Latium Phytoclimate Map (Blasi, 1994), the above plant formations fall into the following phytoclimatic units:

- Temperate bioclimatic region: unit 2, summits of lower carbonate massif with lower montane thermotype and upper humid ombrotype; units 3 and 4, Apennines intramontane valleys with submontane thermotype and from upper humid to lower hyperhumid ombrotype; unit 6, Sabina piedmont with hilly thermotype and from subhumid to lower humid ombrotype.

- Temperate bioclimatic transition region: unit 7, Middle Tiber valley between Orte and Monterotondo with thermotype from hilly to Mesomediterranean and inferior humid ombrotype. 


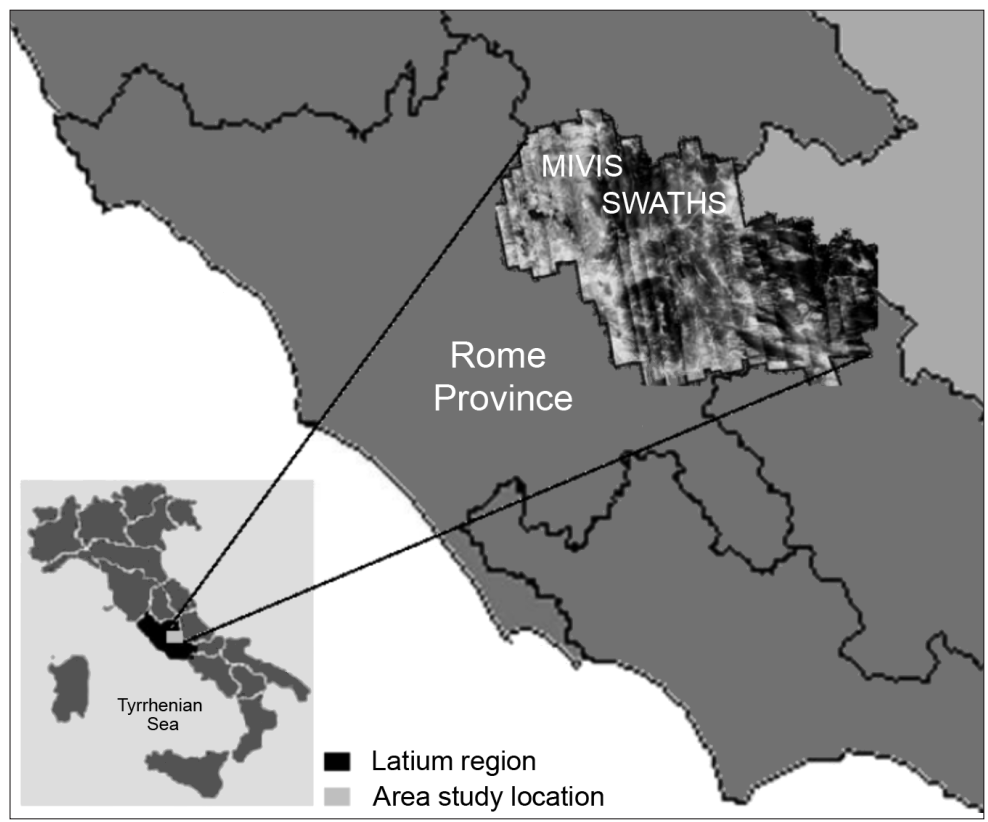

Fig. 1. Location of the study area on Rome Province with MIVIS swaths overlaid.

The whole area shows formations belonging to the Mediterranean environment, like evergreen forests with a prevailing presence of Quercus ilex, and the typical Mediterranean maquis. This Mediterranean maquis which in some spots (mainly in the area of Mt. Catillo) is characterized by the peculiar chorologic eastern component with an abundant presence of Styrax officinalis (protected species by the Regional Law 61/74), Cercis siliquastrum, Paliurus spina-christi, Carpinus orientalis (Montelucci, 1972, 1984).

In the submontane climatic type (between 200 and $600 \mathrm{~m}$ a.s.1.) deciduous species mixed with Quercus pubescens, Quercus cerris and Ostrya carpinifolia are present, at mountain level (between 600 and $1600 \mathrm{~m}$ a.s.l.) Fagus sylvatica is present with a fragmentary distribution while in mountainous areas it is thickly spread (Montelucci, 1978). The articulated morphology and diffuse surface karstification bring about the presence of humid depressions covered by mesophyll prairies with different floristic types.
Arid prairies are diffuse as well, being the consequence of the prolonged exploitation of mountain pastures; they represent the most favourable habitat for the growth of those vegetation species typical to arid environments on carbonatic lithologies. Rocky environments are of particular interest since they also host numerous endemisms and botanic rarities.

\section{Data and processing methods}

MIVIS data campaign, conducted in June 1998, covered an area of about 168225 ha, corresponding to about $31 \%$ of the Province's whole surface. It included 28 runs recorded with relative altitude of about $1700 \mathrm{~m}$, NNW/SSEoriented flight lines, parallel to one another, with approximately $25-30 \%$ overlapped laterally (fig. $2)$. The pixel ground resolution, due to the relative flight altitude, is about $3.4 \mathrm{~m}$.

The MIVIS is composed of 4 spectrometers which measure the electromagnetic Earth radia- 


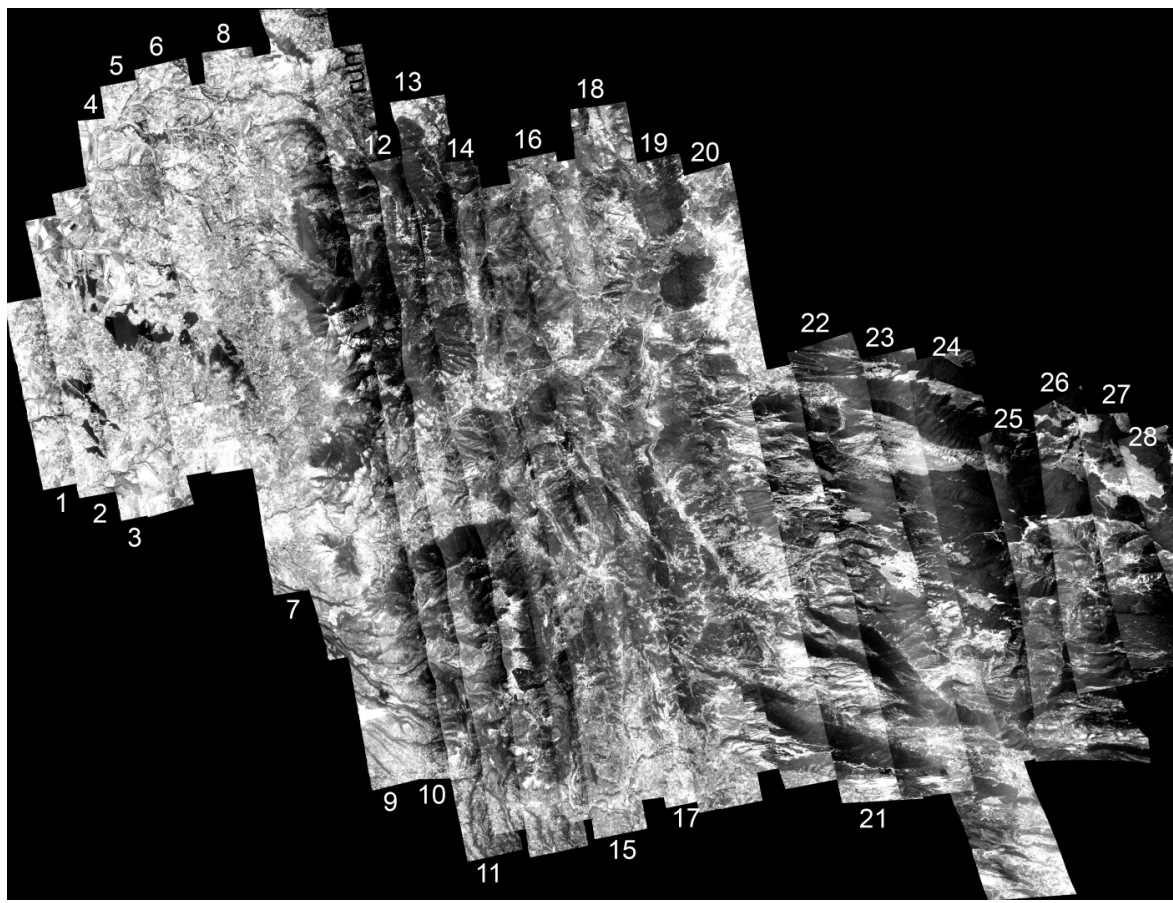

Fig. 2. Mosaic of MIVIS flight lines.

Table I. MIVIS spectral characteristics.

\begin{tabular}{ccccc}
\hline \hline Spectrometer & Spectral region & Bands number & Spectral range $(\mu \mathrm{m})$ & Band width $(\mu \mathrm{m})$ \\
\hline I & Visible & 20 & $0.43-0.83$ & 0.02 \\
II & Near infrared & 8 & $1.15-1.55$ & 0.05 \\
III & Medium infrared & 64 & $2.0-2.5$ & 0.009 \\
IV & Thermal infrared & 10 & $8.2-12.7$ & $0.34-0.54$ \\
\hline
\end{tabular}

tion with 102 spectral bands in the visible, near infrared, middle infrared and thermal infrared regions, with $2 \mathrm{mrad}$ of IFoV (see table I).

The dataset used was the first 28 bands (I and II spectrometer) covering the spectral range $0.43-1.55 \mu \mathrm{m}$ because this spectral region corresponds to the maximum reflectance of vegetation and encompasses the major spectral features related to the biophysical characteristics of the plants. The bands of the III and IV spectrometers were not employed because they did not produce any meaningful improvements in the classification process and they increased processing time.

MIVIS data have been radiometrically calibrated using references inside the sensor, and the Radiance Factor was measured on optical bench; this operation converted the sensor's electromagnetic radiation, expressed in Digital Numbers (DN), into radiance $\left[\mathrm{nW} /\left(\mathrm{cm}^{2} \mathrm{~nm} \mathrm{sr}\right)\right]$. MIVIS images were then corrected for the path radiance atmospheric component by means of 
simulations performed with the MODTRAN code (Berk et al., 1989), since such effect on a scene produces classification errors.

The geometric correction was carried out through a software developed in IDL language by LARA (Avanzi et al., 1997, 2006) which enabled us to correct the airborne attitude platform during flight for panoramic distortions, (due to yaw, pitch, roll, drift, altitude and speed variations) and the morphological variations of the Earth surface. These corrections (fig. 3) were performed taking into consideration both the system acquisition geometry and the airborne navigation data. The topographic variations of the countryside territory were instead corrected by means of the Digital Elevation Model (DEM) derived from satellite interferometry techniques with a resolution of $30 \mathrm{~m}$ (courtesy of ESA-ESRIN). The residual errors due to the not perfect reconstruction of the airplane's trajectory and ground elevation were minimized using the Ground Control Points (GCP) extracted from the Regional Technical Map (scale 1:10000). The image warping was
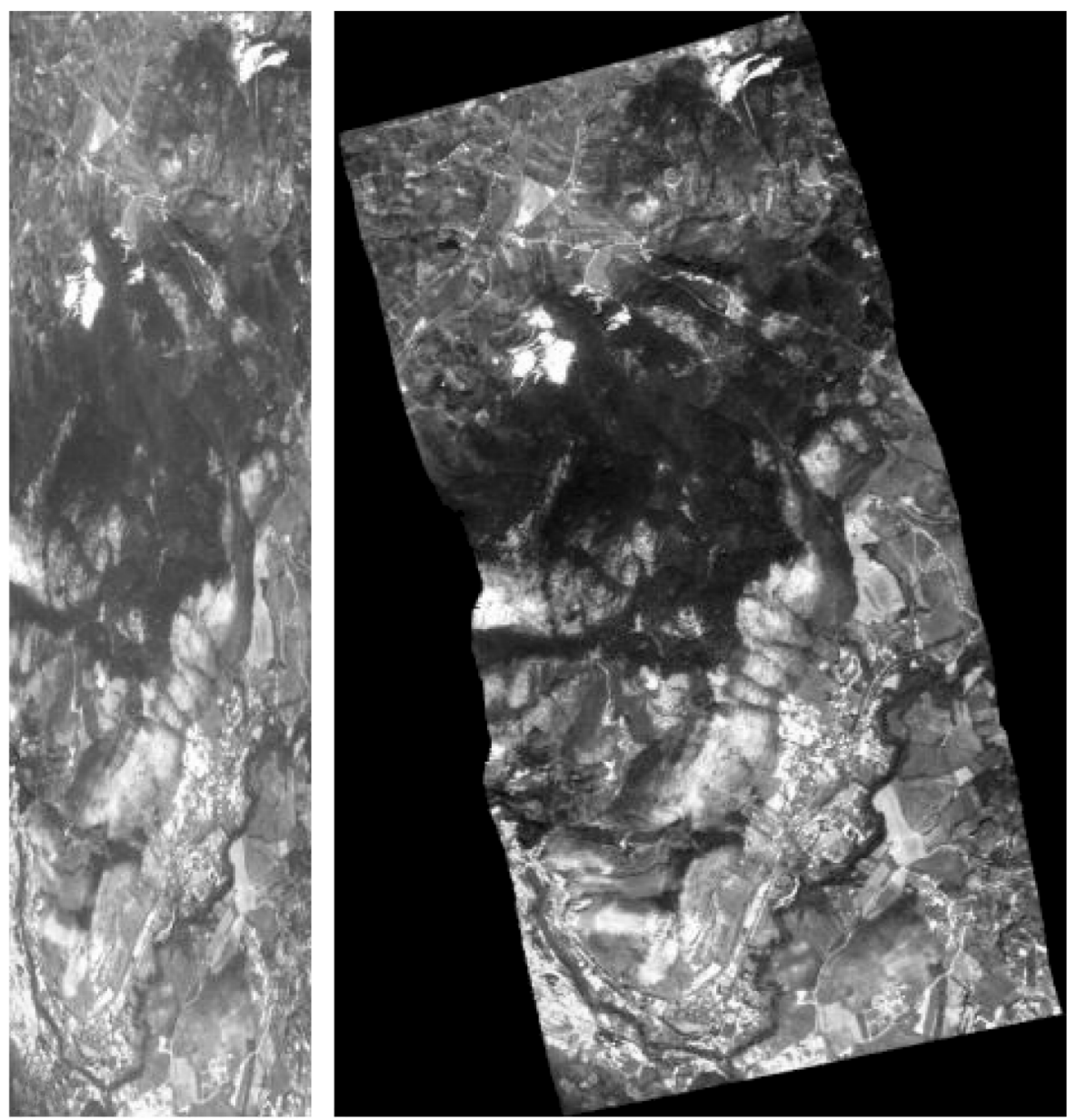

Fig. 3. Geometric correction: (left) uncorrected image; (right) geometrically corrected image. 
accomplished in one single phase by means of a «Nearest Neighbour» re-sampling.

This pre-processing chain methodology was developed and then tested on the four Natural Reserves, as their vegetation complexity constitutes a suitable test bench to experiment and improve the different techniques adopted.

In view of the botanic and naturalistic importance of these Natural Reserves, the Map of Prevailing Vegetation Classes was produced at 1:10000 scale (Cavalli et al., 2001), while the corresponding map referring to the entire airborne remotely sensed area is at 1:25000 scale. In addition to the Map of the Main Vegetation Classes, other specific thematic maps have been produced concerning some environmental and phytosanitary indicators like soil humidity, dry vegetation, NDVI (Normalized Difference Vegetation Index) and NDWI (Normalized Difference Water Index; Gao, 1996).

\section{Implementation of the Map of the Main Vegetation Classes}

To manage the great quantity of available data as best as possible, a relatively simple methodology has been defined, which could be reproducible and applicable to all remotely sensed runs. In particular to reduce data processing time and minimize the drawbacks occurring during image mosaiking, the area was divided into 3 sectors, each one with its own morphologic and environmental characteristics. The first sector is constituted by the mosaic of runs 1 to 7 , characterized by mainly plain and hilly areas. The second one is formed by the mosaic of the runs 8 to 18 , mostly characterized by sub-mountain and mountain ranges. The third one comprises the mosaic of runs 19 to 28 , especially characterized by mountain and high relief surfaces. These areal divisions also minimized the problem of the non uniform distribution of ground truths in all the scenes for each spectral class.

To facilitate the image supervised classification, a first discrimination of the main homogeneous land cover classes was defined by photointerpreting MIVIS images (see table II) to create uniform spectral classes.

Informative layers were then produced by digitizing on screen their limits (so obtaining vector files), covering the following classes: arable lands, permanent crops, urban areas, quarries, waters, natural environments. Vector layers so obtained were transformed into masks and used to create thematic subsets over which the usual techniques of image processing can be applied for the supervised extraction of spectral classes. In particular to perform the «Map of Prevailing Vegetation Classes», a mask of natu-

Table II. False Color Composites (FCC) and Black and White (BW) images used for photo-interpretation. A-combinations of bands corresponding respectively, for vegetation, to the two bands with higher spectral absorption (red and blue colours) and the one with major reflectivity (green colour): it better approaches the natural colour representation; B-combinations of channels corresponding respectively to the maximum reflectance plateau in the NearInfrared, the water absorption peak and chlorophyll peak; hence, this FCC highlights vegetation covers, discriminating between agricultural lands and spontaneous vegetation; $\mathrm{C}$ - and D-BW images which allow to emphasize less easily detectable covers such as bare soils, vegetation sparse or in relative dryness conditions.

\begin{tabular}{ccccc}
\hline \hline FCC & Red & Green & Blue & BW images \\
\hline A & Ch. 13 & Ch. 7 & Ch. 1 & \\
& $(0.6 \mu \mathrm{m}<\lambda<0.69 \mu \mathrm{m})$ & $(0.53 \mu \mathrm{m}<\lambda<0.57 \mu \mathrm{m})$ & $(0.43 \mu \mathrm{m}<\lambda<0.45 \mu \mathrm{m})$ & \\
B & Ch. 19 & Ch. 28 & Ch. 13 & \\
& $(0.79 \mu \mathrm{m}<\lambda<0.81 \mu \mathrm{m})$ & $(1.50 \mu \mathrm{m}<\lambda<1.55 \mu \mathrm{m})$ & $(0.67 \mu \mathrm{m}<\lambda<0.69 \mu \mathrm{m})$ & \\
C & & & Ch. 28 \\
& & & $(1.50 \mu \mathrm{m}<\lambda<1.55 \mu \mathrm{m})$ \\
D & & & Ch. 93 \\
& & & $(8.21 \mu \mathrm{m}<\lambda<8.56 \mu \mathrm{m})$ \\
\hline
\end{tabular}


Table III. Definitions of prevailing vegetation classes.

\begin{tabular}{llll}
\hline \hline Forest formations & Shrubs formations & Herbaceous formations & Anthropics areas \\
\hline $\begin{array}{l}\text { Evergreen woods with prevalence } \\
\text { of Quercus ilex; Quercus suber }\end{array}$ & $\begin{array}{l}\text { Prevailing deciduous } \\
\text { and evergreen sclerophyll }\end{array}$ & $\begin{array}{l}\text { High mountain pastures } \\
\text { with Sesleria tenuifolia. }\end{array}$ & Arable lands \\
shrubs. & & &
\end{tabular}
and Castaneasativa (only for Catillo Mt. Natural Reserve).

Mixed woods with dominant presence of Quercus cerris; mixed woods with local prevalence of Quercus robur (only for Nomentum and Macchia di Gattaceca Natural Reserves).

Mixed woods with dominant presence of Quercus pubescens.

Mixed woods with dominant presence of Ostrya carpinifolia.

\section{Castanea sativa woods.}

Fagus sylvatica woods.

Riparian Vegetation with dominant presence of Populus alba and Salix alba.

Conifers woods with dominant presence Pinus nigra.

Thickets in evolution; thickets with Cercis siliquastrum, Styrax officinalis, Pistacia terebinthus and Acer monspesulanum (only for Catillo Mt. Natural Reserve).
Shrubs with Crataegus sp. Prunus sp. Spartium junceum, Cytisus sp.; shrubs with Erica arborea, Cystus salvifolius and Spartium junceum (only for Catillo Mt. Natural Reserve).

Mountain and high and high mountain shrubs with prevailing presence Juniperus sp.
Mountain and sub-mountain pastures.
Permanent crops (only for Natural Reserves)

Urban areas

Mesophylous pastures.

\begin{abstract}
Thermophylous pastures with Ampelodesmos mauritanicus; garigues.
\end{abstract}

Bare surfaces; rock outcrops.
Ornamental green

Quarries

Waters

Unclassified ral vegetation was created for each sector using the «natural environments» informative layer; this mask enabled us to improve the classification of vegetation classes as much as possible and to remarkably shorten the processing time. Therefore, this selective approach does classify areas of vegetation included in the natural environments, so removing urban areas, arable lands, etc.
In order to define correct vegetation classes the naturalists of Rome Province carried out several phyto-sociological surveys in situ (in total 160 field surveys performed on the Regional Technical Map at scale 1:10000) according to Braun-Blanquet's method that was further integrated with previous works accomplished in the surveyed area (Brandizzi et al., 1974; Abbate et al., 1981; Avena et al., 1990; Centro Re- 
gionale per la Documentazione dei Beni Culturali e Ambientali, 1993). The main physiognomic classes defined by the naturalist are reported in table III. The in situ observations enabled us to identify spectrally homogeneous classes on the airborne remotely sensed images, useful for defining 133 Regions Of Interest (ROI, as implemented in the ENVI 3.4 software package; RSI, 2000), of which about $70 \%$ as training areas, and $30 \%$ to further classification testing. The ROI were chosen to represent adequately the vegetation classes shown in table III, pertaining to forest, shrub and herbaceous formations for a total of 17 vegetation classes; they were selected within several morphologic contexts to better represent the spectral class variability.

The classification procedure is based on the Maximum Likelihood (ML) algorithm applied to the first 28 bands (spectral range from 0.43$1.55 \mu \mathrm{m})$. The ML classifier was chosen because allows a better recognition of those spectral classes, like the vegetation species, which present very correlated spectra. This algorithm assumes that the statistics for each class in each band are normally distributed and calculates the probability that a given pixel belongs to a specific class (Richards, 1999). Each pixel is assigned to the class that shows the highest probability.

The cartographic restitution of the final thematic product was obtained by mosaiking the three sectors into a GIS-compatible (GeoTIFF) image format, using the Gauss-Boaga East time zone reference system (fig. 4).

\section{Results and discussion}

The «Map of Prevailing vegetation classes» (fig. 4) also reproduces other classes pertaining to the anthropic formations defined in table II. The surface percentages of the cover classes found the study area are as follows: forest formations $35.10 \%$, shrub formations $15.23 \%$, herbaceous formations $14.18 \%$, bare surfaces and rock outcrops $0.65 \%$, Waters bodies $0.11 \%$, arable lands $30.71 \%$, urban areas $3.92 \%$, quarries $0.11 \%$; consequently the natural and semi-natural area covers about $65 \%$ of the entire study area.
The classification accuracy of the thematic map was estimated by confusion matrix and $K$ coefficient (see table IV). Overall accuracy is computed by dividing the total correct pixels (sum of the major diagonal) by the total number of pixels in the confusion matrix. Kappa analysis is a discrete multivariate technique used in accuracy assessments, that is a measure of agreement or accuracy (Congalton, 1991). The evaluation procedure applied to the data gave an overall accuracy equal to $80.69 \%$ and a $K$ coefficient equal to 0.7899 .

The classification produced good results in the discrimination of forest and shrub formations and herbaceous formations. In particular, between forest formations the methodology well discriminated conifers from broadleaves (e.g., Pinaceae from Fagaceae), and between broadleaves, evergreens from deciduous ones (e.g., Quercus ilex woods from Castanea sativa woods), mainly in those areas where broadleaves form pure and well developed forests. Less accurate results were obtained for the classes that form mixed woods, among them: mixed woods with dominant presence of Quercus cerris; mixed woods with dominant presence of Quercus pubescens and mixed woods with dominant presence of Ostrya carpinifolia. The large vegetation biodiversity was highlighted locating and mapping also vegetation classes with limited extension and circumscribed within certain areas, or local prevailing species inside more extended formations. From this point of view, the location and mapping of Quercus suber woods and Cercis siliquastrum thickets, of high naturalistic and environmental value, located in the Catillo Mt. Natural Reserve, also represented an important result. It was possible to localize Quercus robur communities within into Quercus cerris woods, present in the Nomentum and Macchia di Gattaceca Natural Reserves. The identification of areas with «anomalous» spectral responses (in the sector between the villages of S. Vito Romano and Capranica Prenestina, Prenestini Mt.), interpreted as Castanea sativa woods deteriorated by parasites' attack, proved to be interesting as a future application hypothesis. Moreover it was possible to map complex vegetation covers (mainly shrubby formations), otherwise difficult to locate with traditional techniques. The integrated ap- 


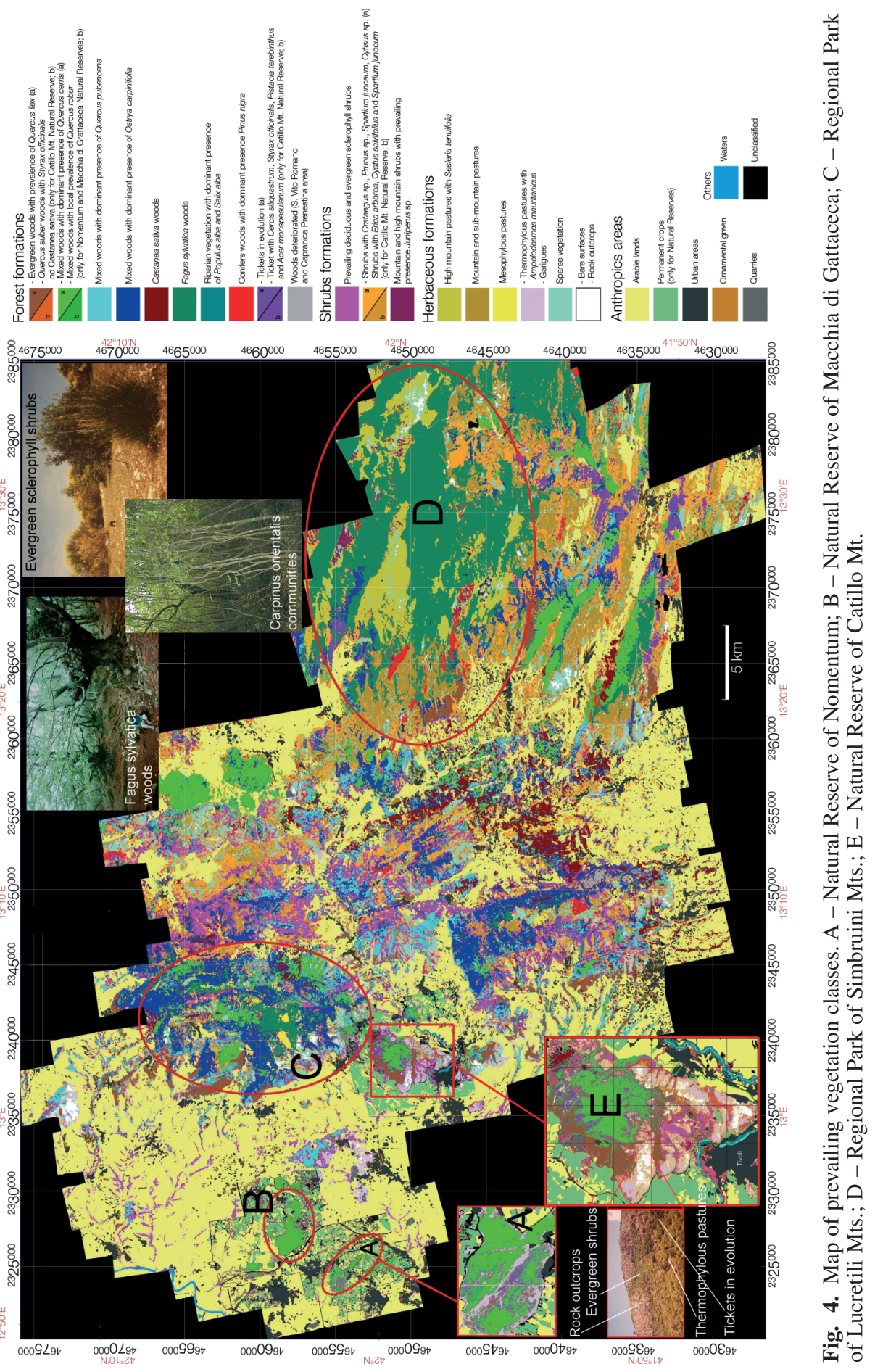


Table IV. Confusion matrix.

\begin{tabular}{|c|c|c|c|c|c|c|c|c|c|}
\hline \multicolumn{10}{|c|}{ Ground Truth (pixels) } \\
\hline $\begin{array}{l}\text { Confusion } \\
\text { matrix }\end{array}$ & $\begin{array}{l}\text { Sparse } \\
\text { veget. }\end{array}$ & $\begin{array}{c}\text { Crataegus sp., } \\
\text { Spartium } \\
\text { junceum, } \\
\text { Cytisus sp. }\end{array}$ & $\begin{array}{c}\text { Deciduous, } \\
\text { evergreen } \\
\text { shrubs }\end{array}$ & $\begin{array}{c}\text { Rock } \\
\text { outcrops }\end{array}$ & $\begin{array}{l}\text { Mesoph. } \\
\text { pastures }\end{array}$ & $\begin{array}{l}\text { Shrubs with } \\
\text { Juniperus sp. }\end{array}$ & $\begin{array}{c}\text { Thermoph. } \\
\text { pastures }\end{array}$ & $\begin{array}{l}\text { Thickets } \\
\text { in evolution }\end{array}$ & $\begin{array}{r}\text { Mountain } \\
\text { pastures }\end{array}$ \\
\hline \multicolumn{10}{|l|}{ Class } \\
\hline Unclassif. & 6 & 23 & 28 & 34 & 12 & 15 & 39 & 107 & 12 \\
\hline Sparse veg. & 373 & 0 & 0 & 0 & 0 & 0 & 0 & 0 & 1 \\
\hline $\begin{array}{l}\text { Crataegus sp., } \\
\text { Spartium } \\
\text { junceum, } \\
\text { Cytisus sp. }\end{array}$ & , 0 & 125 & 5 & 0 & 0 & 9 & 0 & 59 & 0 \\
\hline $\begin{array}{l}\text { Deciduous, } \\
\text { evergreen } \\
\text { shrubs }\end{array}$ & 0 & 0 & 280 & 0 & 1 & 12 & 0 & 27 & 19 \\
\hline $\begin{array}{c}\text { Rock } \\
\text { outcrops }\end{array}$ & 0 & 0 & 0 & 305 & 0 & 0 & 2 & 0 & 0 \\
\hline $\begin{array}{l}\text { Mesoph. } \\
\text { pastures }\end{array}$ & 0 & 2 & 0 & 0 & 442 & 17 & 0 & 0 & 11 \\
\hline $\begin{array}{l}\text { Shrubs with } \\
\text { Juniperus sp. }\end{array}$ & 0 & 3 & 2 & 0 & 6 & 258 & 0 & 0 & 16 \\
\hline $\begin{array}{l}\text { Thermoph. } \\
\text { pastures }\end{array}$ & 4 & 0 & 0 & 0 & 0 & 2 & 400 & 0 & 0 \\
\hline $\begin{array}{l}\text { Thickets } \\
\text { in evolution }\end{array}$ & 0 & 10 & 3 & 0 & 0 & 0 & 0 & 473 & 0 \\
\hline $\begin{array}{l}\text { Mountain } \\
\text { pastures }\end{array}$ & 0 & 0 & 6 & 0 & 7 & 11 & 0 & 1 & 533 \\
\hline $\begin{array}{l}\text { Quercus } \\
\quad \text { ilex }\end{array}$ & 0 & 2 & 3 & 0 & 0 & 0 & 0 & 8 & 0 \\
\hline $\begin{array}{l}\text { Quercus } \\
\text { cerris }\end{array}$ & 0 & 0 & 0 & 0 & 0 & 0 & 0 & 0 & 0 \\
\hline $\begin{array}{c}\text { Ostrya } \\
\text { carpinifolia }\end{array}$ & 0 & 0 & 0 & 0 & 0 & 1 & 0 & 2 & 0 \\
\hline $\begin{array}{l}\text { Castanea } \\
\text { sativa }\end{array}$ & 0 & 0 & 0 & 0 & 1 & 0 & 0 & 4 & 0 \\
\hline $\begin{array}{c}\text { Fagus } \\
\text { sylvatica }\end{array}$ & 0 & 0 & 0 & 0 & 0 & 0 & 0 & 0 & 0 \\
\hline $\begin{array}{c}\text { Quercus } \\
\text { pubescens }\end{array}$ & 0 & 0 & 8 & 0 & 2 & 6 & 0 & 9 & 0 \\
\hline Riparian veg. & 0 & 3 & 0 & 0 & 0 & 1 & 0 & 0 & 0 \\
\hline Conifers & 0 & 0 & 0 & 0 & 0 & 0 & 0 & 0 & 0 \\
\hline Total & 383 & 168 & 335 & 339 & 469 & 331 & 441 & 687 & 592 \\
\hline
\end{tabular}

proach between image processing and photointerpretation disclosed 22 land cover classes.

In particular, the analysis of the map shows that in the western sector (to west of Tivoli city), chiefly characterized by covers deriving from anthropic activities, the areas devoted to sowing cultivations, woody cultivations (with a large diffusion of olive trees) and pastures prevail. It is al- 


\begin{tabular}{|c|c|c|c|c|c|c|c|c|c|}
\hline $\begin{array}{l}\text { Quercus } \\
\text { ilex }\end{array}$ & $\begin{array}{l}\text { Quercus } \\
\text { cerris }\end{array}$ & $\begin{array}{c}\text { Ostrya } \\
\text { carpinifolia }\end{array}$ & $\begin{array}{l}\text { Castanea } \\
\text { sativa }\end{array}$ & $\begin{array}{c}\text { Fagus } \\
\text { sylvatica }\end{array}$ & $\begin{array}{l}\text { Quercus } \\
\text { pubescens }\end{array}$ & $\begin{array}{l}\text { Riparian } \\
\text { vegetation }\end{array}$ & Conifers & Total & $\begin{array}{l}\text { Confusion } \\
\text { matrix }\end{array}$ \\
\hline
\end{tabular}

\begin{tabular}{|c|c|c|c|c|c|c|c|c|c|}
\hline & & & & & & & & & Class \\
\hline 34 & 101 & 164 & 26 & 39 & 67 & 1 & 4 & 710 & Unclassif. \\
\hline 0 & 0 & 0 & 0 & 0 & 0 & 0 & 0 & 374 & Sparse veg. \\
\hline 2 & 0 & 0 & 10 & 0 & 1 & 1 & 0 & 212 & $\begin{array}{l}\text { Crataegus sp., } \\
\text { Spartium } \\
\text { junceum, } \\
\text { Cytisus sp. }\end{array}$ \\
\hline 1 & 1 & 8 & 0 & 0 & 12 & 0 & 1 & 360 & $\begin{array}{l}\text { Deciduous, } \\
\text { evergreen } \\
\text { shrubs }\end{array}$ \\
\hline 0 & 0 & 0 & 0 & 0 & 0 & 0 & 0 & 307 & $\begin{array}{c}\text { Rock } \\
\text { outcrops }\end{array}$ \\
\hline 0 & 0 & 0 & 5 & 0 & 1 & 0 & 0 & 477 & $\begin{array}{l}\text { Mesoph. } \\
\text { pastures }\end{array}$ \\
\hline 0 & 0 & 0 & 4 & 0 & 0 & 2 & 0 & 290 & $\begin{array}{l}\text { Shrubs with } \\
\text { Juniperus sp. }\end{array}$ \\
\hline 0 & 0 & 0 & 0 & 0 & 0 & 1 & 0 & 407 & $\begin{array}{l}\text { Thermoph. } \\
\text { pastures }\end{array}$ \\
\hline 13 & 1 & 2 & 2 & 0 & 4 & 0 & 0 & 508 & $\begin{array}{l}\text { Thickets } \\
\text { in evolution }\end{array}$ \\
\hline 0 & 0 & 0 & 0 & 1 & 0 & 0 & 0 & 559 & $\begin{array}{c}\text { Mountain } \\
\text { pastures }\end{array}$ \\
\hline 451 & 0 & 17 & 1 & 0 & 70 & 6 & 18 & 575 & $\begin{array}{c}\text { Quercus } \\
\text { ilex }\end{array}$ \\
\hline 3 & 485 & 92 & 0 & 114 & 8 & 0 & 0 & 702 & $\begin{array}{c}\text { Quercus } \\
\text { cerris }\end{array}$ \\
\hline 1 & 26 & 422 & 0 & 27 & 22 & 0 & 0 & 501 & $\begin{array}{c}\text { Ostrya } \\
\text { carpinifolia }\end{array}$ \\
\hline 1 & 1 & 0 & 668 & 2 & 0 & 0 & 0 & 676 & $\begin{array}{c}\text { Castanea } \\
\text { sativa }\end{array}$ \\
\hline 0 & 26 & 66 & 0 & 733 & 0 & 0 & 0 & 825 & $\begin{array}{c}\text { Fagus } \\
\text { sylvatica }\end{array}$ \\
\hline 87 & 10 & 81 & 4 & 0 & 327 & 0 & 5 & 538 & $\begin{array}{c}\text { Quercus } \\
\text { pubescens }\end{array}$ \\
\hline 28 & 0 & 0 & 0 & 0 & 1 & 197 & 2 & 231 & Riparian veg. \\
\hline 14 & 0 & 0 & 0 & 0 & 4 & 0 & 492 & 510 & Conifers \\
\hline 636 & 649 & 853 & 720 & 916 & 515 & 208 & 521 & 8762 & Total \\
\hline
\end{tabular}

so possible to note an evident building development of urban centers, mainly along the most important roads, and a diffuse and progressive urbanization of the surrounding countryside. The most significant and extended natural areas are located in or very close to the Natural Reserves (Nomentum and Macchia di Gattaceca), last evidence of a habitat, once more extended, which 
characterized the so called «agro romano», namely the countryside around Rome.

The central and eastern sectors (to east of Tivoli city), mainly mountainous, are mostly characterized by relatively intact habitat, with wide continuous natural areas or in progress of re-naturalization, extended and compact forest formations which are well developed, diffused prairies and large shrubby formations. Shrubby formations present a broader variety in their floristic composition and spatial distribution, forming, together with some pastures and sparse or grouped trees, vegetation mosaics characterized by a great lack of cover homogeneity, and giving the relevant land a wide variability of the distributive pattern of herbaceous, shrubby and arboreal components. Such variability especially occurs where agricultural activities are being progressively deserted (a phenomenon common enough in this area) and uncultivated soil is tending to re-naturalize. Anthropic activites are mainly concentrated along valleys (Aniene Valley) and plain areas.

\section{Conclusions}

The multidisciplinary formulation given to the research activity planning, with the constant contribution of expertise from different disciplines, like botanists, naturalists and remote sensing experts, has certainly aided in the good outcome of the project.

The thematic maps produced have been helpful in the preliminary drawing up of the Management Plans of the Natural Reserves, which should constitute the reference for the future land management policy and the enhancement of biocompatible activities, in respect and safeguard of the environment.

The developed methodology enabled us to rapidly and practically process MIVIS data covering wide land extensions, and to attain the map of the main vegetation classes with a good confidence. The application of such procedure also permitted us to produce maps with ancillary information of interest for the environmental planners of the Province Administration. With reference to this the Rome Province Administration is completing the management and environmental recovery plans of the areas Mt. Soratte, Mt. Guadagnolo, Travertini Acque Albule (Tivoli), pertaining in the area study, indicated to the European Community as area SIC and ZPS.

The additional maps show other land cover types, such as the different agricultural crops (e.g., corn, wheat, beetroot, etc), artificial surfaces in urban areas (brick, asbestos-cement, etc.).

The MIVIS image processing procedures applied in this project are characterized by the use of the correction of the atmospheric contribution due to the path radiance, a geometric correction procedure (including the land orography) and particularly for the application of selective criteria between informative layers of the main land cover classes (first level classes in the classification hierarchy). This procedure then enabled us to process many adjacent scenes in a fast and practical manner, to manage classes statistically homogeneous, and as a consequence to produce thematic maps at different scales characterized by relatively high $K$ values.

The use of the above described procedures allows us to develop a follow-on phase which will likely include classification refinements in areas presenting a strong dynamism, and the better diversification of some vegetation types (e.g., shrubby and herbaceous communities). The availability of a DEM will also permit us to carry out a morphological study of the area with reference to the relations between morphological classes and vegetation classes, as already made on the area of Mt. Soratte.

Based on the encouraging results obtained so far by means of the airborne remotely sensed data on the area of Rome Province, interesting scenarios can be hypothesized for a future development of common activities (CNR - Local Authorities) finalized to plan and implement of effective actions for the safeguard and management of vegetation and forest resources.

\section{Acknowledgements}

The authors are grateful to Maurizio Poscolieri for valuable discussions and to Angela Mirabelli for help in improving the paper. 


\section{REFERENCES}

Abbate, G., G.C Avena, C. Blasi and L. Veri (1981): Carta della vegetazione del M.te Soratte 1:10000, in Studio delle Tipologie Fitosociologiche del Monte Soratte (Lazio) e loro Contributo nella Definizione Fitogeografica dei Complessi Vegetazionali Centro-Appenninici (P.F. «Promozione della qualità dell'ambiente» CNR, Roma), AQ/1/125, 1-41.

Avanzi, G., C.M. Marino and S. Pignatti (1997): Geocodifica e mosaico su modello altimetrico digitale di immagini MIVIS, in Atti della I Conferenza Nazionale ASITA, p. 179

Avanzi, G., A. Palombo and S. Pignatti (2006): MIVIS image geocoding experience on merging position attitude system data and public domain GPS stream (ASIGeoDAF), Ann. Geophysics, 49 (1), 11-20 (this volume).

Avena, G.C., L. Bonifazi, S. Fascetti and L. Rubeca (1990): Carta della Vegetazione del Territorio della IX Comunita' Montana del Lazio, Compreso nei Limiti del Parco dei M.ti Lucretili (scala 1:25000), (Dipartimento di Biologia Vegetale, Università degli Studi di Roma «La Sapienza»).

BERK, A., L. BERNSTEIN and D. RoBERTSON (1989): MODTRAN: a Moderate Resolution Model for LOWTRAN7, Final Report, GL-TR-0122, AFGL, Hanscom AFB, p. 42.

Blasi, C. (1994): Fitoclimatologia del Lazio, Fitosociol., 27, 151-175.

BoraK, J.S., E.F. LAmbin and A.H. STRAhler (2000): The use of temporal metrics for landcover change detection at coarse spatial scales, Int. J. Remote Sensing, 21 (67), 1415-1432.

Brandizzi, G., A. Angelucci, A .Biasini, G. Casella, R. Funiciello, M. Giannini, G. Giovagnoli, L. RampiCHINI, A. PANAscÈ and G. Bigi (1974): Carta Agroforestale della Provincia di Roma (Camera di Commercio, Industria, Artigianato e Agricoltura di Roma).

Cavalli, R.M., L. Fusilli, A. Guidi, S. Panzarasa, S.PigNATTI, A. Vinci and C.M. MARINo (2001): Dati iper- spettrali telerilevati per la gestione di riserve naturali della Provincia di Roma, in Atti della V Conferenza nazionale ASITA, vol. I, 477-482.

Centro Regionale per la Documentazione dei Beni Culturali ed Ambientali (1993): Carta del Paesaggio vegetale della Valle del Tevere (scala 1:50000), (Ass.to alla Cultura - Regione Lazio).

Congalton, R.G. (1991): A review of assessing the accuracy of classifications of remotely sensed data, Remote Sensing Environ., 37, 35-46.

Congalton, R.G., K. Green and J. Teply (1993): Mapping old-growth forest on National Forests and park lands in the Pacific Northwest from remotely sensed data, Photogramm. Eng. Remote Sensing, 59, 529-535.

GAO, B.-C. (1996): NDWI - A Normalized Difference Water Index for remote sensing of vegetation liquid water from space, Remote Sensing Environ., 58, 257-266.

HiLl, J., J. Megier and W. MeHL (1995): Land degradation, soil erosion, and desertification monitoring in Mediterranean ecosystems, Remote Sensing Rev., 12, 107-130.

LAmBIN, E.F. (1998): Modeling and monitoring land-cover change pro-cesses in tropical Regions, Prog. Phys. Geogr., 21 (3), 375-393.

Montelucci, G. (1972): Considerazioni sul componente orientale nelle foreste della Penisola, Ann. Accad. Ital. Sci. For, XXI, 121-169.

Montelucci, G. (1978)(1976-1977): Lineamenti della vegetazione nel Lazio, Ann. Bot. (Roma), XXXL-VI, 1107.

Montelucci, G. (1984): I monti di Tivoli dal punto di vista botanico, Natura e Montagna, 3, 37-48.

Moreno, J.M. and W.C. OECHEL (Editors) (1995): Global Change and Mediterranean-Type Ecosystems (New York, Springer-Verlag), p. 527.

Nemani, R. and S.W. RunNING (1996): Global vegetation cover changes from coarse resolution satellite data, $J$. Geophys. Res., 101, 7157-7162.

RichardS, J.A. (1999): Remote Sensing Digital Image Analysis (Springer-Verlag), p. 240.

RSI (2000): ENVI User's Guide (Research Systems Inc.), 261-288. 